\title{
ダム貯水池による河川水の流域内滞留時間 の変化に関する検討 ON THE CHANGE OF BASIN SCALE RIVER WATER RESIDENCE TIME BY DAM RESERVOIRS
}

\author{
馬籠純 $1 \cdot$ 竹内邦良 $2 \cdot$ 金丸茂男 $3 \cdot$ 石平博 4 \\ Jun MAGOME, Kuniyoshi TAKEUCHI, Shigeo KANEMARU and Hiroshi ISHIDAIRA \\ 1学生会員 山梨大学大学院 工学研究科（广400-8511 山梨県甲府市武田4-3-11） \\ 2正会員 工博 山梨大学教授 工学部土木環境工学科（テ400-8511 山梨県甲府市武田4-3-11） \\ 3学生会員 山梨大学大学院 工学研究科（广400-8511 山梨県甲府市武田4-3-11） \\ 4正会員 工博 山梨大学助教授 工学部土木環境工学科（†400-8511 山梨県甲府市武田4-3-11）
}

\begin{abstract}
The purpose of this study is to understand the potential impact of reservoir induced water storage on the basin scale water cycle. In this study, the increase of the basin scale residence time of river water is used as the index of the effect of reservoir on water cycle, and its spatial and temporal distribution in Japan are demonstrated. The results of analysis show that the potential increase of residence time by dam reservoirs in Japan has gradually increased from 1960's and reached to 14.5 days in 1995. The actual residence time increase is also estimated in the Tone river basin where operation and seasonal variation of river discharge are taken into account. It is shown that the estimated actual residence time is much smaller than the potential, in the case of the Tone river basin, $45 \%$.
\end{abstract}

Key Words : Residence time, Dam reservoir, Water storage in reservoirs, Runoff

\section{1. はじめに}

1998年現在、世界では堤高が15m以上のものだけで、 41413 個以上ものダム貯水池があると報告されている1。 全世界の1年間に利用可能な河川水は約 $12500 \mathrm{~km}^{3}$ とされ ている が、これらダム貯水池の合計貯水容量は、その 約半分に当る $6000 \mathrm{~km}^{3}$ を超え、また、満水時湛水面積の 合計は、フランスの国土面積に相当する約 50 万 $\mathrm{km}^{2}$ であ る3)。これらダム貯水池により開発された水資源は、河 川、湖沼、地下水などと共に、都市、農業、工業用水の 水源として用いられている。また、ダム貯水池は、洪水 調節機能、水力発電による電力供給源、さらには観光、 レクリエーションなど様々な便益を社会にもたらしてい る。

一方で、ダム貯水池は河川水を滞留させるため、水循 環過程への影響も少なくない。河川水の帯留は、貯水池 内における土砂堆積、富栄養化を引き起こすだけでなく、 その上流域に排水不良、土砂堆積、下流域に河道水不足、
河床低下、さらに水生生物の移動、生息阻害などの影響 を及ぼす。このようにダム貯水池は、水を滞留させるこ とにより、流水や土砂、栄養塩等の物質輸送過程を通じ、 河川の化学、生物環境にも様々な影響を及ぼす。した がって、ダム貯水池の機能維持および適切な河川管理を 行うためには、ダム貯水池による流域地表水の滞留時間 を定量的に把握し、水循環へ与える影響を明らかにする ことが必要である。

ダム貯水池による水の滞留に伴う影響に関しては、こ れまでにも多くの検討がなされてきている。例えば、安 藝、白砂ら ${ }^{4)}$ は、日本国内の貯水池内における水の交換 率と水温、密度構造との関係について検討し、貯水池に よる滞留の影響を評価している。また、Vorosmarty et $\mathrm{e} 1^{5)}$ は貯水池がその流域へ及ぼす影響に関して、0.5 メッシュひ全球河道網と貯水容量 $0.5 \mathrm{~km}^{3}$ 以上の人ダムの 貯水容量から、ダム貯水池による河川水の滞留時間の分 布をグローバルスケールで検討し、大河川の河口部にお いて3ケ月を超えるような流出遅れがあることを示して いる。しかしながら、帯留時間増加の流域内分布、地域 


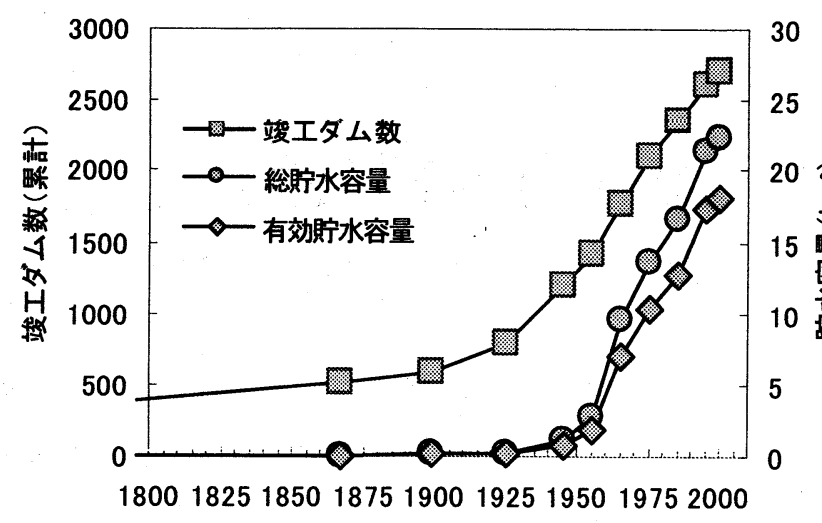

竣工年度

図-1日本のダム貯水池建設の推移

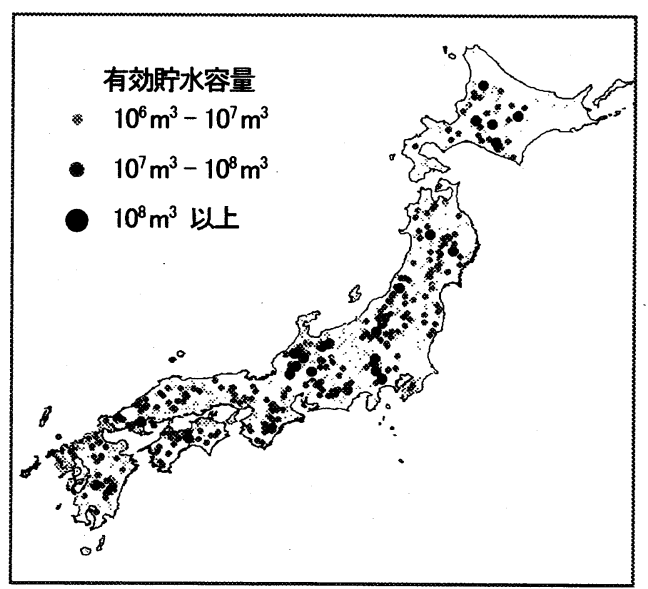

図-3日本のダム貯水池の分布（1995現在）

分布、季節変化等、各地域での帯留時間に関する詳細は、 まだ十分に検討されていない。

そこで、本研究では河川水の滞留時間の増加（3節参 照）を指標として、ダム貯水池の建設が水の滞留を通じ て水循環へ与える影響の評価を試みる。すなわち、日本 国内のダム貯水池を対象として、ダム貯水池における平 均滞留時間、および流域、地域毎の平均滞留時間の変化 について検討するとともに、流域内における上流加ら下 流までの貯水池による滞留時間の分布について検討・考 察する。

\section{2. 日本におけるダム貯水池の建設状況}

\section{（1）ダム貯水池建設の推移}

図-1は、ダム年鑑（2001年度版） ${ }^{6)}$ をとに、日本国 内の堤高が $15 \mathrm{~m}$ 以上のダム貯水池について、建設数とそ の累計貯水容量の変化を示したものである。なお、種々 の統計データでは一般的に高さ $15 \mathrm{~m}$ 以上の水資源施設を ダムとして集計しており、これ以降、ダム貯水池とは以

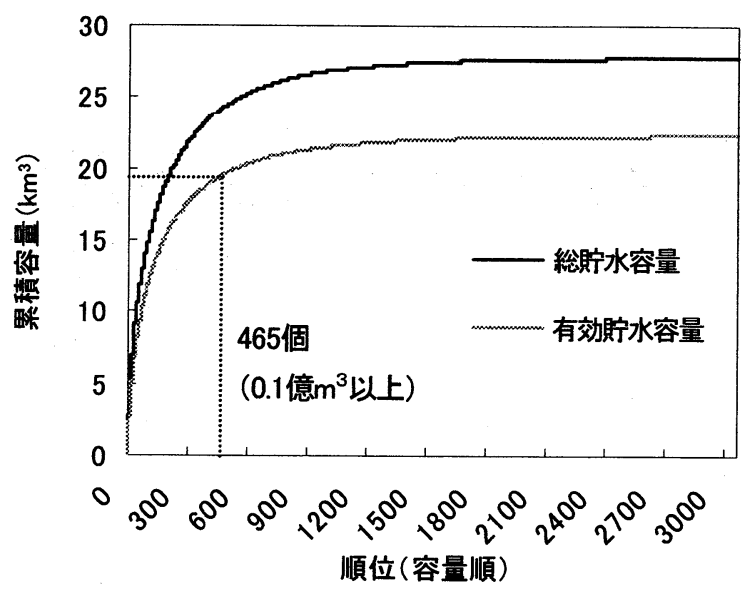

図-2 日本のダム貯水池の累加貯水容量曲線

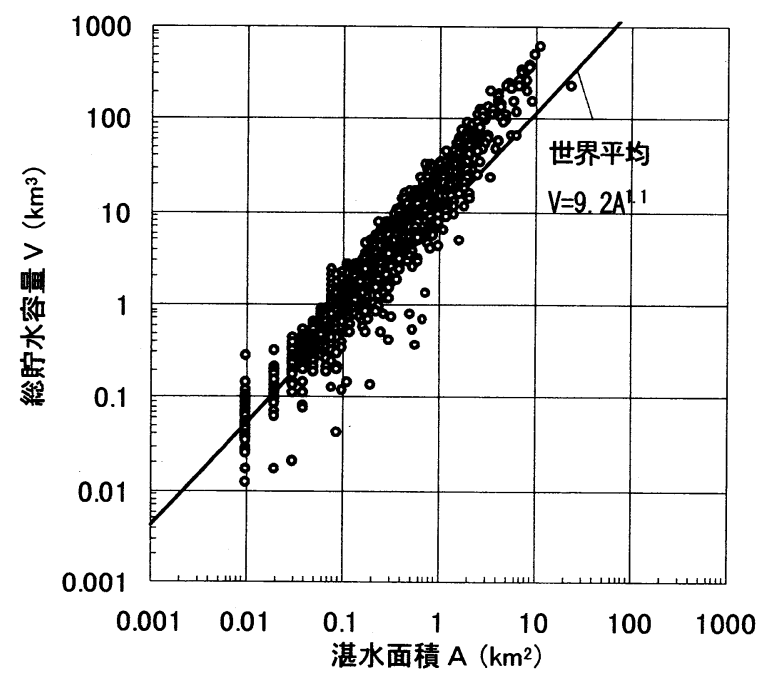

図-4 日本のダム貯水池の湛水面積-貯水容量関係

上の定義に従うものとする。図-1より、竣工ダム数は、 1945年から2000年にかけて1199個から2704個と増加し、 この 55 年間で現在の $56 \%$ \%建設されている。総貯水容量 については、この期間で現在の $95 \%$ 創出している。ま た増加率は、ダム数、貯水容量ともに1955年以降で大き くなっている。特に貯水容量の増加率が大きいことから、 この期間に比較的大規模なダム貯水池が建設されたこと が分かる。

\section{(2) ダム貯水池の累加貯水容量}

図-2は、国土数值情報ダムファイル（W01-07P）の データをもしに、貯水容量が記載されている3070個のダ 厶貯水池の貯水容量を、今後の計画分も含め、大きいも のから容量順に累加したものである。有効貯水容量でみ た場合、（3070個の約1／6に相当する） 0.1 億 $\mathrm{m}^{3}$ 以上の 465個のダム貯水池で、日本全体の $87 \%$ の容量を占めて いることがわかる。

\section{（3）ダム貯水池の分布}

ダムファイル (W01-07P) より得られるダム位置（緯 
経度）と貯水容量をもとに、1995年における総貯水容量 100 万 $\mathrm{m}^{3}$ 以上のダム貯水池の分布を図-3に示す。ダム貯 水池は全国に建設されており、容量の大きなものは山地 部に多くみられ、特に北陸および群馬・新潟・福島の県 境付近に大規模なものが多い。

\section{（4）湛水面積一貯水容量関係}

ダム年鑑（2001年度版） ${ }^{6)}$ 記載の湛水面積と総貯水容 量およびダムファイルのデータをもとに、計1553個のダ 么貯水池の湛水面積 (A) - 貯水容量 (V) 関係を図-4 に示す。比較のために、世界各国7936個のダム貯水池に おける常時満水位時のA、Vより求めた、世界の平均的な $A-V$ 関係 (竹内 ${ }^{7)}$ ) も合わせて示した。これより、日本 のダム貯水池は世界の平均的なダム貯水池と比べて、同 じ湛水面積に対してより大きな貯水容量をもっており、 湛水面積、貯水容量の比でみると、急峻な山岳地に効率 の良いダム貯水池が多く建設されていることが分かる。

\section{3．滞留時間の定義}

滞留時間の増加は、ダム貯水池による水、栄養塩、土 砂などの物質輸送過程の変化を通じて、河川の化学、生 物環境へ大きな影響を及ぼすと考えられている。この滞 留時間は、水がある領域に流入してから流出するのに要 する時間であり、貯水容量/流入量で定義される。しか し、この定義は押し出し形態の流出を仮定した場合であ り、流入・流出、混合、通過経路によって、水の滞留時 間は異なる。

本研究では、平均滞留時間を指標として、ダム貯水池、 ダム貯水池の存在する流域、地域の平均滞留時間、およ び流域内における滞留時間の分布を以下のように求め、 検討を行う。

\section{a）ダム貯水池における平均滞留時間}

$$
T_{R}=\frac{V_{R}}{Q_{i}}
$$

ここで、 $T_{R}$ はダム貯水池での平均滞留時間、 $V_{R}$ は対象 ダム貯水池の有効貯水容量、 $Q_{i}$ は対象ダム貯水池一の平 均流入量である。

b) 流域および地域毎の平均滞留時間

$$
T_{\text {ave. }}=\sum V_{R} / Q_{o}
$$

$T_{\text {ave }}$ はダム貯水池を含む対象領域（流域、もしくは地 域)の平均的な滞留時間、 $V_{R}$ は対象領域内に位置寸るダ 厶貯水池の有効貯水容量、 $Q_{0}$ は対象領域出口の流量であ る。

\section{c）流域内における滞留時間の分布}

流域内における滞留時間の分布の検討では、 Vorosmarty et $\mathrm{el}^{5)}$ の定義を用いる。まず、対象とする

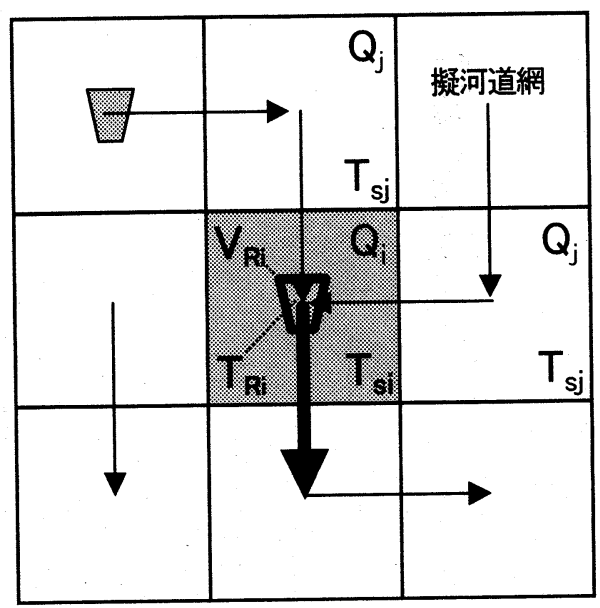

図-5 滞留時間の定義 (Vorosmarty et $\mathrm{el}^{5}$ )

流域内をメッシュ分割し、これらのメッシュを落水線理 論により作成される擬河道網で接続する。次に、各メッ シュにおいて、ダム貯水池の有效貯水容量 $V_{R i}$ による滞 留時間増加分 $T_{R i}$ を求め、これに上流のダム貯水池によ る滞留時間を加えた合計の滞留時間を河川水の滞留時間 $T_{s i}$ として、以下の式で求める（図-5）。

$$
\begin{aligned}
& T_{R i}=\frac{V_{R i}}{Q_{i}} \\
& T_{s i}=\frac{\sum T_{s j} \cdot Q_{j}}{Q_{i}}+T_{R i}
\end{aligned}
$$

式( $\left.1^{\prime}\right)$ の $V_{R i}$ はメッシュ $\mathrm{i}$ のダム有効貯水容量、 $Q_{i}$ は メッシュiでの流量である。式(3) の $T_{s j}$ および $Q_{j}$ は、 メッシュiに流入するメッシュでの河川水滞留時間と流 量である。

\section{4. 㴆留時間の計算と考察}

\section{（1）ダム有効貯水容量と流量}

滞留時間を求めるにあたり、次のデータを使用した。 ダム貯水池の有効貯水容量Vについては、ダム年鑑お よび国土数值情報ダムファイルから取得した。また、ダ ム位置はダムファイルの值を用いた。

流量Qについては、降水量 $(\mathrm{mm} /$ 年) から蒸発散量 (mm/年) を差し引き、対象地域の面積 $\left(\mathrm{km}^{2}\right)$ を乗じて求 めたものを用いた。ここで、降水量は気象庁観測平年值 より約 $1 \mathrm{~km} の メ ッ シ ュ$ 統計值を使用した。また、日本の ような湿潤な地域ではThornthwaite法が流域全体の実蒸 発散量と良く一致することが野上 ${ }^{8)}$ によって指摘されて

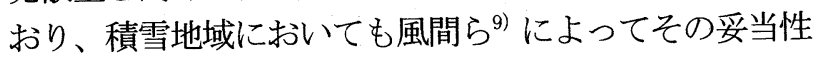
が確認されている。そこで、本研究では気温のメッシュ 統計值から、Thornthwaite法により蒸発散量を推定した。 


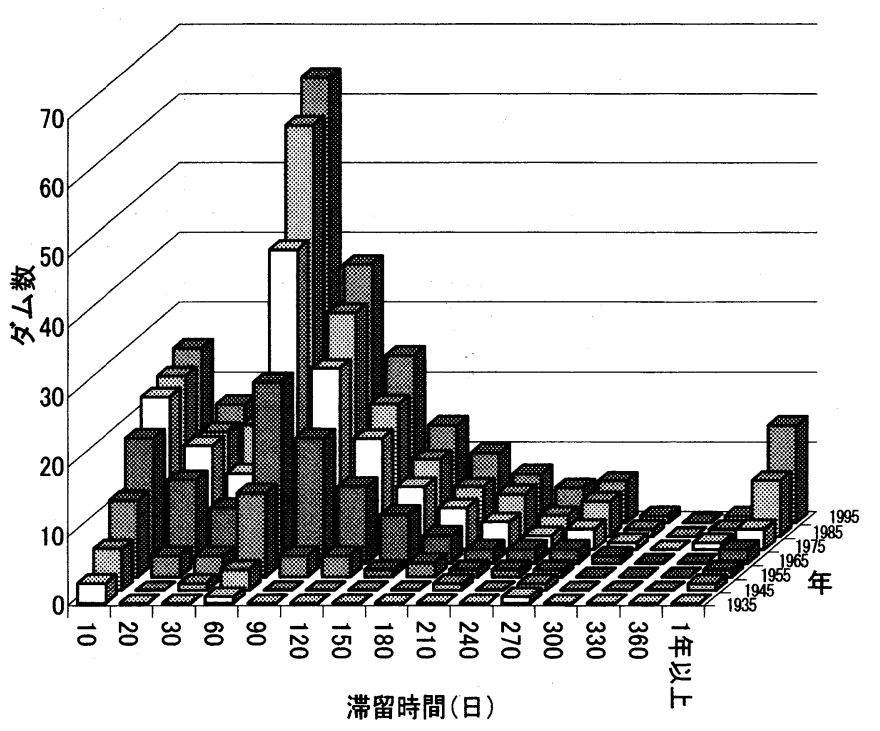

図-6ダム貯水池における平均滞留時間の分布

（2）滞留時間の計算

\section{a）ダム貯水池における平均滞留時間}

本研究では、一級河川109水系における、国土交通省 監修の流量年表に記載されている最下流流量観測地点の 上流域に位置し、1995年以前に建設された合計241個の ダム貯水池を対象とした。なお、この 241 個の総有効貯 水容量は、1995年時点での日本全体の約70\%である。ま た、ダム貯水池への流入量 $Q_{i}$ は、前述の方法でメッシュ 統計値より求めた最下流流量観測地点の流量から、その 流域面積と各ダム貯水池の流域面積の比によって算出し、 式(1)によりダム貯水池の滞留時間を求めた。

図-6は、得られた帯留時間を、1935年時点から1995年 までの年代別のヒストグラムで表したものである。まず、 各年代とも滞留時間は幅広く分布している。また、極端 に長いものや短いものも存在することがわかる。これは 流入量に対し、極端に有効貯水容量の大きな、もしくは 小さなダム貯水池があることに対応しており、各貯水池 の利用目的に大きく影響していると考えられる。また 1955年以降で増大しており、近年は、滞留時間の長いダ 么貯水池が増えている傾向が同える。このことは、この 期間に大規模な貯水容量を持つダム貯水池が建設された こと、および、比較的流量が小さな上流域にダム貯水池 が建設されたことを示すと考えられる。

\section{b）流域および地域毎の平均帯留時間}

流域および地域毎の平均的な滞留時間は、メッシュ統 計値より求めた対象領域出口の流量 $Q_{0}$ と各ダム貯水池の 有効貯水容量 $V_{R}$ から、式(2)により計算した。

図-7は一級河川の最下流流量観測地点における流域 109水系の流域平均滞留時間である。1965年から1995年 まで10年間隔で計算したが、ここでは1995年のものを示 す。全体的に西日本で短く東日本で長い傾向が見られる。

また、図-8は、日本の各地域における滞留時間の経年 変化である。各地域とも増加傾向であり、全国平均は

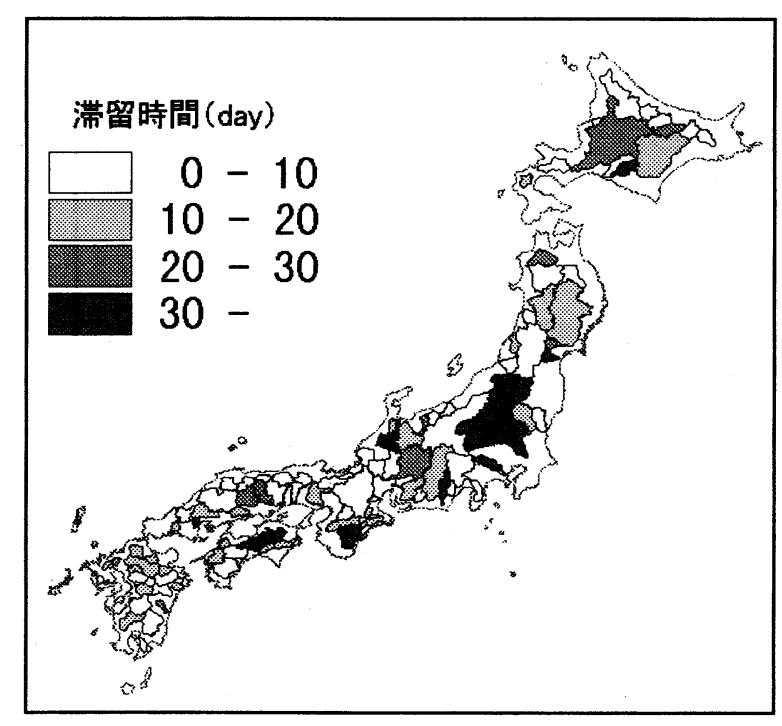

図-7 流域の平均滞留時間（1995年）

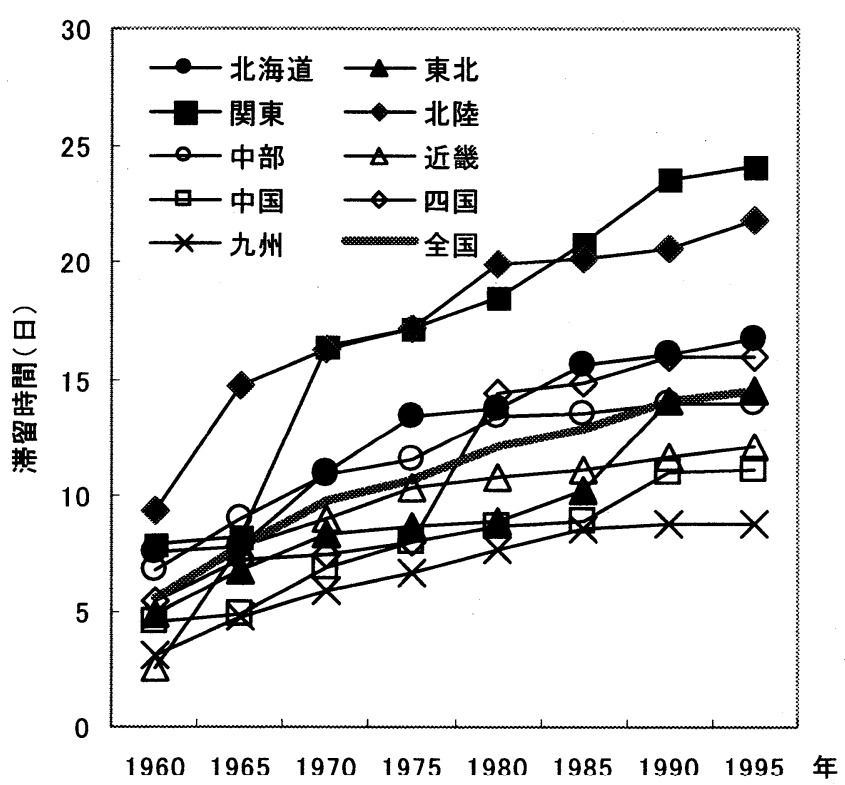

図-8＼cjkstart地域毎の平均滞留時間の変化

1960年から1995年に5.5日から14.5日と約1.6倍に増加し ている。この日本の平均滞留時間14.5日は、全世界の平 均滞留時間約175日（1年間の平均利用可能な河川水を約 $12500 \mathrm{~km}^{3}$ 、ダム貯水池の合計貯水容量を約 $6000 \mathrm{~km}^{3}$ とし た場合）と比較して、かなり小さいと言える。これは世 界的な大ダムに比へ、日本のダムの貯水容量は極めて小 規模である゙ ことを示している。地域別では、図-7にも みられたように、関東、北陸が特に長く、中国、九州で 短いことが分かる。また、滞留時間が急激に増加してい る期間がみられるが、これは大規模ダムの建設時期に対 応している。例えば、関東では1965年から70年の5年間 で約8日増加しているが、これは、この間に矢木沢ダム

（1967年、有効貯水容量1.76億 $\mathrm{m}^{3} ）$ や下久保ダム（1968 年、有効貯水容量 1.2 億 $\mathrm{m}^{3}$ ) の建設により、滞留時間が 大きく増加したものと考えられる。 


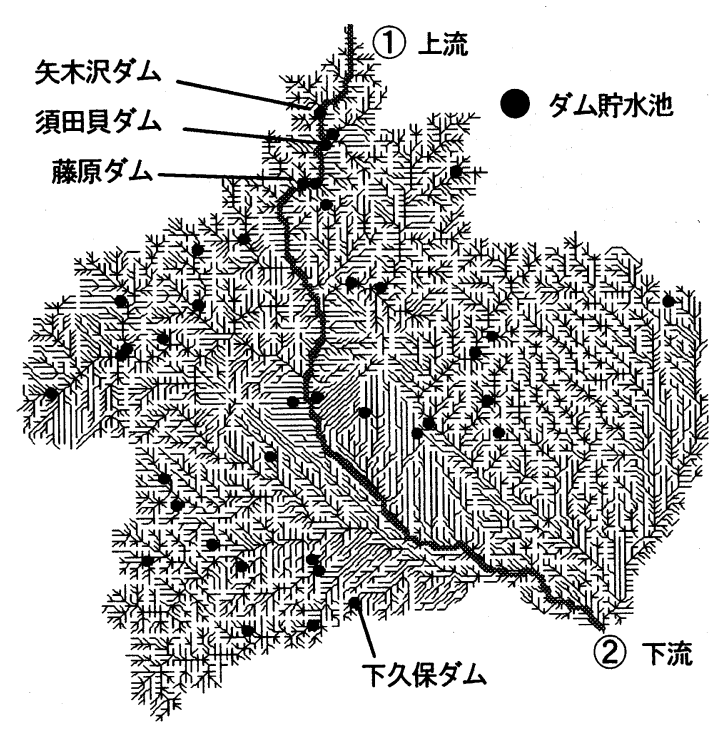

図-9 利根川上流域一擬河道網

\section{c）流域内における滞留時間の分布}

次に、利根川の栗橋流量観測所の上流域（以下、利根 川上流域と表記）を対象とし、流域内における滞留時間 の分布について検討した結果を示す。対象としたダム貯 水池は、合計で39個、その合計有効貯水容量は約6億的 ${ }^{3}$ である。

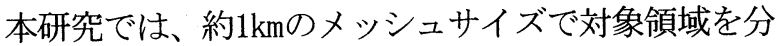
割した。さらに、擬河道網による各メッシュの接続関係 を用いて、式(1')により貯水池の滞留時間 $T_{R i}$ を求めると ともに、式(3)から各メッシュでの滞留時間 $T_{s i}$ を計算し た。用いたDEMは数值地図 $1 \mathrm{~km}$ メシュ（標高）であり、 敖ら ${ }^{10)}$ の手法で得られた擬河道網は図-9のとおりである。 また、各メッシュの流量 $Q_{i}$ は、メッシュ統計值の降水量 とThornthwaite法により推定した蒸発散量から求めた年 平均の流量であり、各ダム貯水池の有効貯水容量 $V_{R i}$ は、 ダムファイルの值を用いた。

図-11の太線（上）は、以上の方法で求めた利根川本 川に沿った（最上流からダム群を通り、出口の栗橋流量 観測所付近まで : 図-9 (1)〜(2)) 滞留時間 $T_{s i}$ の変化を示 している。ここで、矢木沢ダム、須田貝ダム、藤原ダム が運用されている上流区間においては、滞留時間は大き く、下流になるにつれて滞留時間は短くなっている。さ らに、滞留時間の大きな増加が見られた地点は、上流域 の有効貯水容量の大きなダム群の地点に対応している。

上流区間の約 $70 \mathrm{~km}$ 付近までは 100 日以上であり、その下 流は50日未満、最下流では39日となった。また、対象流 域内の 39 個のダム貯水池による滞留時間 $T_{R i}$ は最小で 0.06日、最大で2592日、平均で264日であった。この中 で、滞留時間の大きなものは、上流域の本川沿いではな く、流量は小さいが、容量の大きなダム貯水池であり、 発電用のものも多くみられた。逆に滞留時間の小さなダ 么貯水池は、貯水容量に対して流量の大きい比較的下流 に位置するものと考えられる。

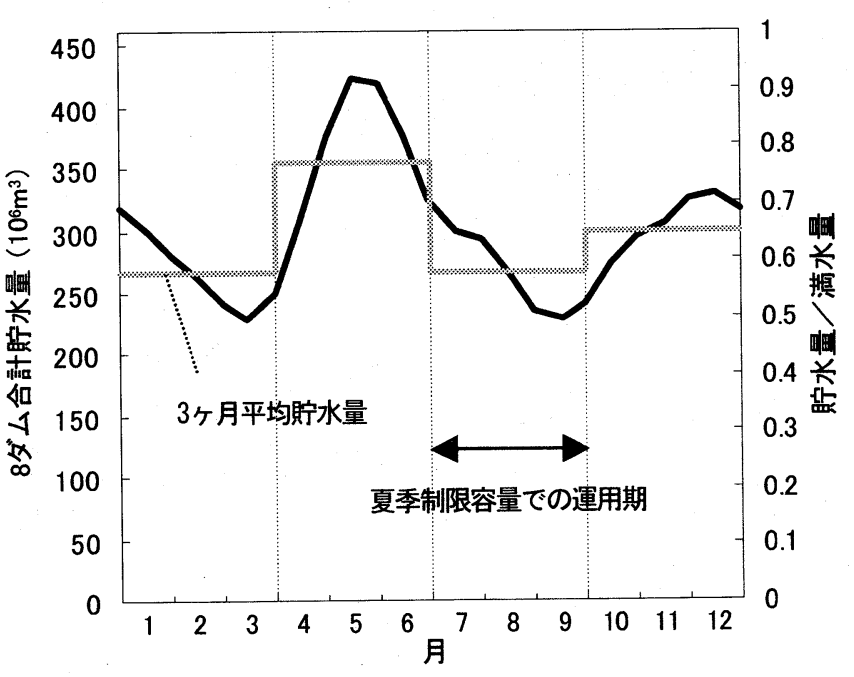

図-10 利根川上流8ダム貯水量変動図（1992-2000年平均）

(利根川ダム統合管理所：http://www.ktr.mlit.go.jp/tonedamu/より)

さらに、同様の手法を大淀川流域、筑後川流域にも適 用した。なお、参考までに、タイ・チャオプラヤ流域 （総貯水容量約 95 億 $\mathrm{m}^{3}$ のSirikitダムを含む）に対して も、同様の検討を行った。その結果、河口部の滞留時間 $T_{s i}$ けそれぞれ12月、8日、193日（約6.4ヶ月）、ダム貯 水池による滞留時間 $T_{R i}$ は平均で86日、12日、807日（約 2.2 年）となった。この結果から次のことが伺える。 Vorosmarty et $\mathrm{el}^{\mathrm{5})}$ も指摘しているように、大陸の大流 域・大貯水池は流域出口においても数ヶ月スケールの滞 留時間をもたらす。これに対して、日本の流域は数日か ら10数日程度（河口部）であり、滞留時間は比較的短い。 この違いは、日本と世界との貯水容量規模の差によると 考えられる。

\section{(3) 考察}

（2）で求めた滞留時間は、流域での貯留がダム貯水 池のみであること、水利用による水の損失および河道外 からの還元水は無いこと、さらにダム貯水池の貯水量 $V$ を有効貯水容量 (一定值) として求めたものである。ま た、流量 Qも実測值ではなく、降水量から蒸発散量を差 し引いた年平均の流量を用いている。これらの意味で、

(2)における滞留時間はダム貯水池による年平均のポテ ンシャル滞留時間と考えられる。しかし、実際のダム貯 水池では、貯水池操作により、図-10のように貯水量が 変動する。また、ダム貯水池一の流入量も、気温、降水 量と同様に季節変動がある。

そこで、より現実的な条件での滞留時間について考察 するため、利根川上流域を対象として、（2）で求めた流 域内滞留時間の分布と、貯水量の変化および流量の変化 を考慮した場合の滞留時間の分布との比較を行った。こ こでは、各ダム貯水池の有効貯水容量 $V_{R i}$ を利根川上流8 ダム (矢木沢、奈良俣、藤原、相俣、薗原、草木、下久 保、渡良瀬遊水地）における1992年から2000年の平均の 


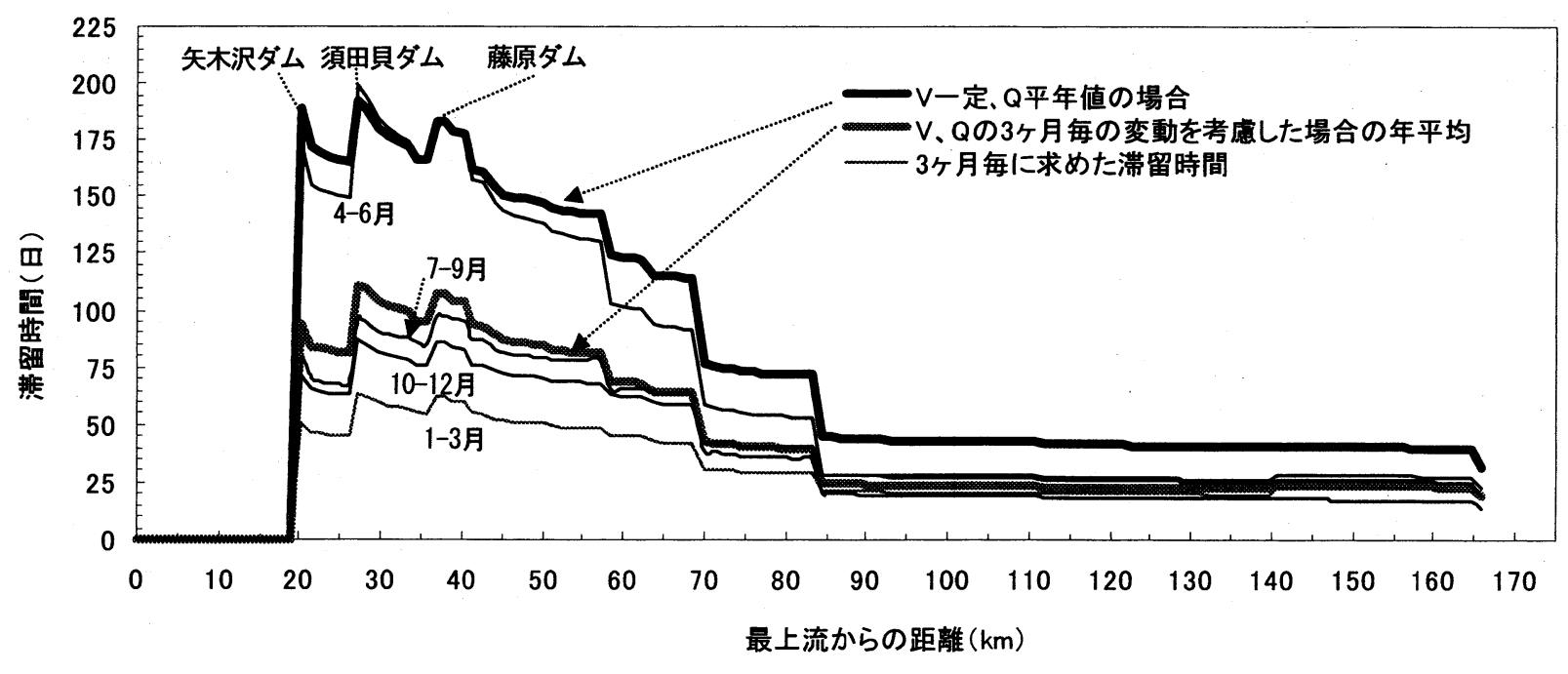

図-11 利根川上流域の滞留時間の分布（図9 (1) (2)の区間)

貯水量変動（図-10）と同じ割合で変動するものと仮定 して、3ヶ月間隔で $V_{R i}$ を変化させた。流量 $Q_{i}$ は、(2)のc) と同様にメッシュ統計值より、3ケ月毎の蒸発散量を推 定し、降水量から差し引いたものを用いた。

図-11は、以上の方法で求めた河川水の滞留時間 $T_{s i}$ の 分布である。太線 (下) は3ヶ月毎の計4時期の帯留時間 を平均したもので、貯水量 $\mathrm{V} 、$ 流量Qの変動を考慮した場 合の年平均の滞留時間である。このようにして求めた滞 留時間は、太線（上）のVが一定でQが平年值のポテン シャル滞留時間と比較して、どの河道区間においても滞 留時間は小さな值をとり、平均で約 $45 \%$ と半分以下と なった。つまり、現実のダム貯水池による滞留時間は、 ポテンシャルの帯留時間に比べてかなり小さいと考えら れる。実際、夏季制限容量でVが小さくQが比較的大きい 7-9月期には、滞留時間は短くなると思われる。そこで、 細線の7-9月期における滞留時間の計算結果を確認する と、ポテンシャル帯留時間の約 $40 \%$ 前後であり、以上の 推察と対応している。また、それ以外の期間では、冬季 を含む10-12月期、1-3月期の両時期に流量Qが小さくな り、4-6月期は大きくなるため、帯留時間は前者で比較 的大きく、後者で小さいと考えられる。しかし、今回の 検討では、上流部で流量Qが冬季で降雪分のため過大評 価、4月の融雪期で過小評価となったため、そのような 傾向は見出せなかった。これは、降水量と蒸発散量の差 をそのまま流量Qとすることでは、3 も降雪、融雪の影響から正確な水収支は得られないこと によると思われる。

\section{5. まとめ}

本研究では、ダム貯水池が水循環に及ぼす影響を定量 的に示すため、日本におけるダム貯水池の建設状況を把 握するとともに、ダム貯水池による滞留時間増加の地域
分布、流域内での滞留時間の変化を求めた。以下に、そ の結果を示す。

(1) 日本全国の平均的なポテンシャル滞留時間は近年増 加してきており、1995年で約14.5日となった。

(2) 貯水池操作による貯水量変動と流量の季節変動によ り、実際の帯留時間はポテンシャル滞留時間よりも小さ いと考えられ、利根川上流域では約 $45 \%$ であった。

今後は、貯水池による水の滞留時間の増大に伴う、士 砂および栄養塩の物質輸送に対する影響についても検討 を行いたい。

\section{参考文献}

1) ICOLD: World register of Dams 1998, International Commission on Large Dams, Paris., 1998.

2) Igor A. Shiklomanov: World water resources: Modern assessment and outlook for the 21-st century, World Freshwater Resources (CD-ROM), 1999.

3) 竹内邦良 : ダム建設の現状と将来, ダム技術, No. 119, 1996.

4) 安藝周一, 白砂孝夫 : 貯水池污濁現象の調査と解析, 電力中 研技術第二研究所報告, 1974

5) Vorosmarty et el: The Storage and Aging of Continental Runoff in Large Reservoir Systems of the World, Ambio, Vol.26 No.4, pp. 210-219, 1996.

6) 日本ダム協会 : ダム年鑑2001, 2001.

7) Takeuchi. K.: On the scale diseconomy of large reservoirs inland occupation, IAHS Publication, No.240, pp.519-527, 1996.

8) 野上道夫 : 暖かさの指数と流域蒸発散量一気候值メッシュデー 夕による解析一, 地理学誌, Vol.99, No. 6, pp. 144-156, 1990.

9) 風間聡, 沢本正樹 : 積雪のある流域における水収支について, 水工学論文集, 第38巻, pp. 113-118, 1994.

10)敖天其, 竹内邦良, 石平博 : 大河川の擬河道網作成におけ る問題点および流出解析への影響, 水工学論文集, 第45巻, pp. 139-144, 2001.

(2001. 10.1受付) 